\title{
Genus Diversity of Actinomycetes in Cibinong Science Center, West Java, Indonesia
}

\author{
YANTYATI WIDYASTUTI ${ }^{1}$, PUSPITA LISDIYANTI $^{1}$, SHANTI RATNAKOMALA ${ }^{1}$, GINA \\ KARTINA $^{1}$, RONI RIDWAN ${ }^{1}$, ROHMATUSSOLIHAT ${ }^{1}$, NITA ROSALINDA PRAYITNO ${ }^{1}$, EVI \\ TRIANA ${ }^{2}$, NUNUK WIDHYASTUTI ${ }^{2}$, RASTI SARASWATI ${ }^{3}$, RATIH DEWI HASTUTI $^{3}$, \\ YULIN LESTARI ${ }^{4}$, MISA OTOGURO $^{5}$, SHINJI MIYADOH ${ }^{5}$, HIDEKI YAMAMURA $^{5}$, \\ TOMOHIKO TAMURA ${ }^{5}$, AND KATSUHIKO ANDO ${ }^{5}$
}

\author{
${ }^{\prime}$ Research Center for Biotechnology, Indonesian Institute of Sciences (LIPI), Jalan Raya Bogor Km 46, \\ Bogor 16911, Indonesian; \\ ${ }^{2}$ Research Center for Biology, Indonesian Institute of Sciences (LIPI), Jalan Raya Jakarta-Bogor Km 46, \\ Bogor 16911, Indonesia; \\ ${ }^{3}$ Indonesia Soil Research Institute, Departement of Agricultutre, Jalan Tentara Pelajar No 12, Bogor 16114, Indonesia; \\ ${ }^{4}$ Faculty of Mathematics and Sciences, Institut Pertanian Bogor, Dramaga Campus, Bogor 16680, Indonesia, \\ ${ }^{5}$ NITE Biological Resource Center, National Instituite of Technology and Evaluation, \\ Kazusakamatari, Kisarazu-shi, Chiba, Japan
}

\begin{abstract}
Actinomycetes are microorganisms that play important role to support human health and known as soil microorganisms. The aim of the research was to describe genus diversity of actinomycetes in Cibinong Science Center (CSC), West Java. Samples for isolation were soil and plant litters. The samples were air dried and ground. We employed isolation methods: dry heat (DH), sodium dodecyl sulphates-yeast extract (SDS-YE), rehydration and centrifugation (RC), and oil separation (OS). A total of 263 isolates of actinomycetes were isolated in CSC, in 2004-2006. Totally 58, 144, 50, and 11 isolates were isolated under each isolation methods, respectively. All isolates were identified using the 16S rRNA gene sequencing method. The results showed that the isolates were belonged to the family Kineosporiaceae, Micromonosporaceae, Nocardiaceae, Pseudonocardiaceae, Streptomycetaceae, Streptosporangiaceae, Mycobacteriaceae, Nocardioidaceae, Nocardiopsaceae, and Thermomonosporaceae. There were 23 genera under those families. Homology value of the isolates based on BLAST search using 16S rRNA gene sequence data as queries showed that 136, 91, 30, and 6 isolates were $\geq 99$, 98,97 , and $\leq 96 \%$, respectively, compared to the known sequence in data base. The later 6 isolates were interesting for further identification leading to new taxa. Recognized species of Streptomyces genera under the member of the Streptomycetaceae were dominant among other isolates.
\end{abstract}

\section{Keywords: 16S rRNA gene sequencing, actinomycetes, diversity, Indonesia}

Actinomycetes merupakan mikroorganisma tanah yang mempunyai peran pada bidang kesehatan. Oleh karena itu, upaya pencarian species actinomycetes baru banyak dilakukan. Tujuan penelitian ini adalah melihat keanekargaman actinomycetes tingkat genus di Cibinong Science Center (CSC), Jawa Barat. Sampel untuk isolasi actinomycetes adalah tanah dan serasah. Metode isolasi yang digunakan adalah dry heat (DH), sodium dodesil sulfat-yeast extract (SDS-YE), rehydration and centrifugation (RC), dan oil separation (OS). Sebanyak 263 isolat actinomycetes telah diperoleh dari CSC pada tahun 2004-2006. Dari jumlah tersebut 58 dari metode $\mathrm{DH}, 144$ isolat dari SDS-YE, 50 dari RC dan 11 dari OS isolat. Identifikasi isolat dilakukan menggunakan metoda sekuen gen 16S rRNA. Hasilnya menunjukkan adanya famili Kineosporiaceae, Micromonosporaceae, Nocardiaceae, Pseudonocardiaceae, Streptomycetaceae, Streptosporangiaceae, Mycobacteriaceae, Nocardioidaceae, Nocardiopsaceae, dan Thermomonosporaceae. Dari famili tersebut diperoleh 23 genus. Nilai kesesuaian isolat berdasarkan analisis BLAST menggunakan sekuen 16S gen rRNA sebagai queri dibandingkan dengan species yang terdaftar pada data base menunjukkan bahwa 131, 91, 30, dan 6 isolat masing-masing mempunyai kesamaan sebesar $\leq 99,98,97$, dan $\leq 96 \%$. Enam isolat dengan kesesuaian $\leq 96 \%$ sangat menarik untuk diungkap sebagai taxa baru. Pada penelitian ini, diperoleh isolat terbanyak dari genus Streptomyces.

Kata kunci: actinomycetes, Indonesia, keragaman, sekuensing gen 16S rRNA

Microorganisms play important role in our activities, although some have pathogenic properties but some have positive role to support human life.

*Corresponding author; Phone: +62-21-8754587, Fax:+6221-8754587,E-mail: yantyati.widyastuti@lipi.go.id
Actinomycetes are microorganisms that play important role especially in pharmaceutical industry to support human health. They are potential as a novel source for the discovery of new bioactive compounds. Activities that focused on discovery of new bioactive compound 
for new products of antibiotics are carried out in some parts of the world recently. Different ecological niches showed many interesting new taxa of actinomycetes and soil has been reported as the natural habitat of actinomycetes. Results of isolation of actinomycetes differed depend on condition of soil and vegetation above the soil (Li et al. 2006; Jiang et al. 2008) or mangrove ecosystem (Tamura et al. 2005; Tamura et al.2006).

Indonesia is located in an equatorial area and most of the area is covered by its tropical rain forests. Tropical rain forests has been known to be the most biologically diverse ecosystems for plants, animals and microorganims on earth. Compared to that of plants and animals, information on diversity microorganisms is very limited. So far, there is no report on diversity of actinomycetes from Indonesia. During the collaborative research on ecology and taxonomy of actinomycetes in Indonesia between Indonesia and Japan, we have collected thousands of actinomycetes isolates from several sites in Indonesia. Some interesting new taxa has been reported, including Streptomyces baliensis sp nov. from Bali (Otoguro et al. 2009), Dietzia timorensis from Timor (Yamamura et al. 2010); Actinokineospora baliensis sp. nov., Actinokineospora cibodasensis sp. nov., Actinokineospora cianjurensis sp. nov. from Bali and Cibodas Botanic Garden (Lisdiyanti et al. 2010); and Actinophytocola timorensis sp. nov. and Actinophytocola coralina sp. nov., from Kupang, East Nusa Tenggara (Otoguro et al. 2011). Cibinong Science Center (CSC), West Java, was selected as one site during the study. The aim of the research was to describe genus diversity of actinomycetes in CSC during the period of 2004-2006.

\section{MATERIALS AND METHODS}

Sample Collection and Preparation. Soil and plant litter samples were collected from different locations in CSC in the year of 2004, 2005, and 2006. Soil samples were taken by digging about $15 \mathrm{~cm}$ from the top soil and and put into plastic bag to keep their humidity while plant litter samples were kept in a paper bag. All samples were air dried for 5-7 d, then ground and sieved through a $2 \mathrm{~mm}$ sieve.

Isolation of Actinomycetes. Four different isolation methods for actinomycetes were employed with different target of isolates first Sodium dodecyl sulphate-yeast extract (SDS-YE) (Hayakawa and Nonomura 1989) for general actinomycetes. One g of a dried soil sample was suspended in $10 \mathrm{~mL}$ of water and stirred for $1 \mathrm{~min}$ using a thermo mixer. Then, $1 \mathrm{~mL}$ of this suspension was transferred to SDS-YE solution $(0.05 \%$ of SDS and $6 \%$ of yeast extract were dissolved in $50 \mathrm{mM}$ P-buffer $\mathrm{pH}$ 7.0). The suspension was heated at $40{ }^{\circ} \mathrm{C}$ for $20 \mathrm{~min}$. SDS-YE solution was serially diluted and spread each $0.1 \mathrm{~mL}$ solutions to Humic acid-Vitamin (HV) medium (Hayakawa and Nonomura 1987). Second Rehydration-centrifugation (RC) (Hayakawa et al. 2000) for motile bearing arthrospore actinomycetes. Five hundred mg of dried soil sample were suspended in $10 \%$ of soil extract and P-buffer and kept at $28{ }^{\circ} \mathrm{C}$ for $1 \mathrm{~h}$, to release the zoospores. Elimination of non-motile actinomyetes was carried out by centrifugation at $3000 \mathrm{~g}$ for $20 \mathrm{~min}$. After centrifugation, the buffer was incubated at $28^{\circ} \mathrm{C}$ for $30 \mathrm{~min}$, to sediment the non-motile actinomycetes, while motile actinomycetes are swimming up in the supernatant. Supernatant was serially diluted and spread $0.1 \mathrm{~mL}$ solutions to HV medium. The third dry heat $(\mathrm{DH})$ (Nonomura and Ohara 1969) for heat resistant and rare actinomycetes. One gram of air dried soil samples were put in a glass petri dish and heated in oven at $100-120{ }^{\circ} \mathrm{C}$ for $1 \mathrm{~h}$ to eliminate filamentous bacteria and Streptomyces. The sample $(0.1 \mathrm{~mL}$ solutionswas) serially diluted and spread to $\mathrm{HV}$ medium. Fourth, oil separation (OS) as modification of Ishigami's water-hexane distribution method use of olive-oil instead of hexane (Ishigami et al. 2004) for lypolytic actinomycetes.This method is based on distribution with oil and water. Five hundred $\mathrm{mg}$ of soil sample were suspended in $5 \mathrm{~mL}$ of olive oil and mixed for $5 \mathrm{~min}$. Then, $5 \mathrm{~mL}$ of water were added to oil and mixed again. Oil and water were distributed by centrifugation for $10 \mathrm{~min}$. After centrifugation, $0.1 \mathrm{~mL}$ of oil was spread to $\mathrm{HV}$ medium with addition of Kabicidin $\left(0.75 \mathrm{mg} \mathrm{L}^{-1}\right)$, Nalidixic acid $\left(10 \mathrm{mg} \mathrm{L}^{-1}\right)$, and Chroltetracyclin $\left(50 \mathrm{mg} \mathrm{L}^{-1}\right)$.

HV Medium Preparation. HV agar plates supplemented with kabicidin $\left(0.75 \mathrm{mg} \mathrm{\textrm {L } ^ { - 1 }}\right)$ and nalidixic acid $\left(10 \mathrm{mg} \mathrm{L}^{-1}\right)$ were prepared at least $4 \mathrm{~d}$ before used, for optimum absorption of inoculated samples. Diluted samples were inoculated and spread until dry. Incubation was done at room temperature for 5-20 d, with occasionally observation after $5 \mathrm{~d}$. Plates were kept in a plastic bag and put in paper box.

Isolation and Selection of Actinomycetes. Colonies appeared around $5 \mathrm{~d}$ of incubation represent fast growing and the rest were slow growing actinomycetes. Colonies of interest were picked up using sterile woody tooth pick and inoculated to yeast 
extract-starch (YS) agar plates. Incubation was carried out at room temperature. Morphological observation of colonies grown in YS agar was done under a microscope. Detection of pigment produced by the isolates was observed from both upper and lower sides of the plates. Selection of the isolates was based on their different morphological appearance.

Identification of Isolates Based on 16S rRNA Gene Sequencing. Selected isolates were subjected for sequence analysis of 16S rRNA gene. Genomic DNA of the isolates was isolated using DNA extraction kit (Promega, USA). The 16S rRNA gene of the isolates was amplified by PCR. PCR condition was as follows: pre denaturation $1.5 \mathrm{~min}$ at $96{ }^{\circ} \mathrm{C}$; denaturation $10 \mathrm{sec}$ at $96^{\circ} \mathrm{C}$, annealing $5 \mathrm{sec}$ at $50{ }^{\circ} \mathrm{C}$, elongation $4 \mathrm{~min}$ at $60^{\circ} \mathrm{C}$ (denaturation, annealing and elongation were run for 25 cycles) and final extension 5 min at $72^{\circ} \mathrm{C}$. The PCR product was sequenced using an ABI PRISM 3130 Genetic Analyzer (Applied Biosystem) according to the manufacturer's protocol. Cycle sequencing was performed using 6 primers, i.e. 9F (5'-GAGTTTGATCCTGGCTCAG-3'), 515F (5'GTGCCAGCAGCCGCGGT-3'), 1099F (5'-GCAAC GAGCGCAACCC-3'), 536R (5'GTATTACCGCGG CTGCTG-3'), 1510R (5'-GGCTACCTTGTTACGA3'), and 1541R (5'AAGGAGGTGATCCAGCC-3'). The 16S rRNA gene sequence data were aligned with published sequences of species of the related genus with validly published names available from EMBL/GenBank/DDBJ by using BLAST Search program (Altschul et al. 1990).

Phylogenetic Analysis. The neighbour-joining (Saitou and Nei 1987), maximum-likelihood (Felsenstein 1981) and maximum- parsimony (Fitch 1971) algorithms of the Clustal_X 1.8 program (Thompson et al. 1997) and MEGA version 3.1 (Kumar et al. 2004) were used for constructing a phylogenetic tree. The robustness for individual branches were estimated by bootstrapping with 1000 replicates (Felsenstein 1985). Phylogenetic tree was constructed based on several genera within a family.

\section{RESULTS}

Isolation and Selection of Actinomycetes. CSC is one campus area of the Indonesian Institute of Sciences (LIPI) of about $190 \mathrm{Ha}$, consisting of buildings, roads, ponds and gardens with several vegetations. Characteristic of the area including altitude $161-170 \mathrm{~m}$, temperature $29.9-33.7{ }^{\circ} \mathrm{C}$, humidity $46.9-63 \%$ and $\mathrm{pH}$ of soil 6-6.5. Collection of samples in CSC was carried out almost in the same season between June and September each year. Although there is global climate change, the period of sample collection may represents end of dry season and beginning of rainy season in Indonesia. Different number of soil and plant litter samples from several rhizospheres and vegetations were collected. We used several isolation methods for soil samples and isolated many isolates compare to that of plant litter samples. Number of plant litter samples collected is also less than soil samples. Many colonies grew on HV medium from DH and SDS-YE isolation method and they appeared to be different each other so that we obtained many isolates from these isolation methods. Only RC method was used for isolation of actinomycetes from both soil and plant litter samples. There is no isolate obtained from both soil and plant litter by RC method in 2004, however we obtained many interested isolates by this method in 2005 and 2006. Actinomycetes isolated from plant litter by RC method did not grow well and difficult to purified, therefore no selected representative isolates in 2004 and 2006. We selected 6 isolates from plant litter by RC method in 2005. OS is a new modification method and was employed for soil samples (Table 1).

Selection of interest isolates of actinomycetes was based on morphological observation and selected as representative of those isolates with similar appearance. We tried to select as diverse as possible to describe the genus diversity of actinomycetes in CSC during the study.

Identification of Actinomycetes. We identified 119 isolates of actinomycetes and they belong to 10 genera and 6 families in 2004 (Table 2), there are more genera and families in 2005 (Table 3) and less genera and families in 2006 (Table 4). A total of 263 isolates represented of 10 genera and 10 families of actinomycetes were identified from this study (Table 5).

Phylogenetic Tree of Interesting Isolates. Identification of the interesting isolates and their position in the phylogenetic tree showed that most of the isolates were separated from the known species of actinomycetes. Among the families of actinomycetes present in CSC, family Kineosporiaceae showed a cluster of interesting isolates as candidates of new genera (Fig 1). We found a canditate of new taxa of Verrucosispora from CSC in 2005 (Fig 2).

\section{DISCUSSION}

We collected more soil samples than plant litter. So far actinomycetes were reported mostly isolated from the soil, although some actinomycetes were reported 
Table 1 Actinomycetes isolated and selected during the study

\begin{tabular}{llclcc}
\hline Year & Source & $\begin{array}{c}\text { Number of } \\
\text { samples }\end{array}$ & $\begin{array}{c}\text { Isolation } \\
\text { method }\end{array}$ & $\begin{array}{c}\text { Number of } \\
\text { isolates }\end{array}$ & $\begin{array}{c}\text { Number of selected } \\
\text { isolates }\end{array}$ \\
\hline 2004 & Soil & 10 & DH & 149 & 58 \\
& & & SDS -YE & 232 & 61 \\
& Plant litter & 4 & RC & 0 & 0 \\
\hline 2005 & Soil & 6 & SDS -YE & 78 & 0 \\
& & & RC & 45 & 57 \\
& & & OS & 14 & 28 \\
& Plant litter & 3 & RC & 21 & 11 \\
\hline \multirow{2}{*}{2006} & Soil & 7 & SDS -YE & 74 & 32 \\
& Plant litter & 7 & RC & 64 & 16 \\
\hline
\end{tabular}

Table 2 Genus diversity of actinomycetes isolated from CSC in 2004

\begin{tabular}{|c|c|c|c|c|c|c|c|c|c|c|c|c|c|}
\hline \multirow{2}{*}{ No. } & \multirow{2}{*}{ Family } & \multirow{2}{*}{ No. } & \multirow{2}{*}{ Genus } & \multicolumn{2}{|c|}{ Source } & \multicolumn{3}{|c|}{ Isolation method } & \multicolumn{5}{|c|}{ BLAST result (\%) } \\
\hline & & & & Soil & Total & DH & SDS & Total & $\geq 99$ & 98 & 97 & $\leq 96$ & Total \\
\hline 1. & Kineosporiaceae & 1 & Kineosparia spp. & 1 & 1 & 1 & & 1 & & 1 & & & 1 \\
\hline \multirow[t]{2}{*}{2.} & Micromonosporacea & 2 & Dactylosporangium spp. & 1 & 1 & & 1 & 1 & & 1 & & & 1 \\
\hline & & 3 & Micromonospora spp. & 11 & 11 & 3 & 8 & 11 & 10 & 1 & & & 11 \\
\hline 3. & Nocardiacea & 4 & Nocardia spp. & 5 & 5 & & 5 & 5 & 4 & 1 & & & 5 \\
\hline \multirow[t]{2}{*}{4.} & Pseudonocardiaceae & 5 & Pseudonocardia spp. & 2 & 2 & & 2 & 2 & 1 & 1 & & & 2 \\
\hline & & 6 & Saccharopolyspora spp. & 2 & 2 & 1 & 1 & 2 & & 2 & & & 2 \\
\hline \multirow[t]{3}{*}{5.} & Streptomycetaceae & 7 & Kitasatospora spp. & 3 & 3 & 3 & & 3 & 1 & 2 & & & 3 \\
\hline & & 8 & Streptacidiphilus spp. & 1 & 1 & & 1 & 1 & & 1 & & & 1 \\
\hline & & 9 & Streptomyces spp. & 92 & 92 & 50 & 42 & 92 & 67 & 21 & 3 & 1 & 92 \\
\hline \multirow[t]{2}{*}{6.} & Steptosporangiaceae & 10 & Nonomuraea spp. & 1 & 1 & & 1 & 1 & & & 1 & & 1 \\
\hline & Total & & & 119 & 119 & 58 & 61 & 119 & 83 & 31 & 4 & 1 & 119 \\
\hline
\end{tabular}

from other habitats or substrates such as marine sediments, mangrove mud, composted pig manure and animal dung (Kurtböke 2000). Based on the isolation method used, we collected a huge number of Streptomyces from DH and SDS-YE methods. Actinomycetes are known to be heat resistant and able to stay in soil for a long period in dry soil. Heating of the soil at about $120{ }^{\circ} \mathrm{C}$ showed that Streptomyces are the most heat resistant actinomycetes. SDS-YE method based on SDS-YE solution containing $0.05 \%$ of SDS and $6 \%$ of yeast extract in $50 \mathrm{mM} \mathrm{P-buffer}$ and $\mathrm{RC}$ method which was developed for isolation of motile actinomycetes (Hayakawa et al. 2000) showed that those procedure is suitable for isolation of Streptomyces. Motile actinomycetes usually categorized as rare or non Streptomyces. However, we found many isolates of Streptomyces in the medium. They showed various morphological characteristics among others and interesting to be selected. Using OS method we selected 11 isolates dominated by isolates from Streptomyces, followed by Mycobacterium and Actinomadura genera. Naturally Streptomyces present abundantly in soil and can be isolated easily using all isolated methods used in this study. There are totally 93 from 186 isolates of selected Streptomyces and showed $99 \%$ or more BLAST similarity to the recognized species, this means the rest or a half number of the selected Streptomyces are not described yet. Under the family Streptomycetaceae we also selected 3 isolates of genera Kitasatospora and 1 isolate of genera Streptacidiphilus, with $98 \%$ BLAST similarity to the recognized species.

In general, selected actinomycetes from CSC in this study is dominated by isolates of Streptomyces that constituted about $70 \%$ of the total selected actinomycetes. The rest of the isolates belong to various families of actinomycetes (Table 5) . Isolates belong to single genera of family Mycobacteriaceae, Nocardioidaceae, 
Table 3 Genus diversity of actinomycetes isolated from CSC in 2005

\begin{tabular}{|c|c|c|c|c|c|c|c|c|c|c|c|c|c|c|}
\hline \multirow{2}{*}{ No } & \multirow{2}{*}{ Family } & \multirow{2}{*}{ No } & \multirow{2}{*}{ Genus } & \multicolumn{2}{|c|}{ Source } & \multicolumn{4}{|c|}{ Isolation method } & \multicolumn{5}{|c|}{ BLAST result (\%) } \\
\hline & & & & Soil & Litter & Total & SDS & $\mathrm{RC}$ & OSS & Total & $\geq 99$ & 98 & 97 & Tota \\
\hline \multirow[t]{2}{*}{1} & Kineosporiaceae & 1 & Cryptosporangium spp. & 1 & & 1 & & 1 & & 1 & 1 & & & 1 \\
\hline & & 21 & Kineosporia spp. & 1 & 6 & 7 & & 7 & & 7 & 3 & 3 & 1 & 7 \\
\hline \multirow[t]{3}{*}{2} & Micromonosporacea & 3 & Actinoplanes spp. & 7 & 1 & 8 & & 8 & & 8 & 1 & 3 & 4 & 8 \\
\hline & & 41 & Dactylosporangium spp. & 4 & & 4 & 2 & 2 & & 4 & 4 & & & 4 \\
\hline & & 51 & Micromonospora spp. & 6 & & 6 & 3 & 3 & & 6 & 4 & 2 & & 6 \\
\hline 3 & Mycobacteriaceae & 61 & Mycobacterium spp. & 3 & & 3 & & & 3 & 3 & 3 & & & 3 \\
\hline 4 & Nocardiacea & 71 & Nocardia spp. & 4 & & 4 & 3 & 1 & & 4 & 3 & 1 & & 4 \\
\hline 5 & Nocardioidaceae & 81 & Kribbella & 2 & & 2 & 2 & & & 2 & & 2 & & 2 \\
\hline 6 & Pseudonocardiaceae & 9 & Amycolatopsis spp. & 1 & & 1 & 1 & & & 1 & 1 & & & 1 \\
\hline 7 & Streptomycetaceae & 10 & Streptomyces spp. & 60 & 1 & 61 & 41 & 13 & 7 & 61 & 19 & 31 & 11 & 61 \\
\hline \multirow[t]{3}{*}{8} & Streptosporangiaceae & 111 & Microbispora spp. & 1 & & 1 & & 1 & & 1 & 1 & & & 1 \\
\hline & & 12 & Microtetraspora spp. & 1 & & 1 & 1 & & & 1 & & 1 & & 1 \\
\hline & & 131 & Nonomuraea spp. & 2 & & 2 & 2 & & & 2 & 1 & 1 & & 2 \\
\hline \multirow[t]{2}{*}{9} & Thermomonosporaceae & 14 & Actinomadura spp. & 1 & & 1 & & & 1 & 1 & & & 1 & 1 \\
\hline & Total & & & 94 & 8 & 102 & 55 & 36 & 11 & 102 & 41 & 44 & 17 & 102 \\
\hline
\end{tabular}

Table 4 Genus diversity of actinomycetes isolated from CSC in 2006

\begin{tabular}{|c|c|c|c|c|c|c|c|c|c|c|c|c|}
\hline \multirow{2}{*}{ No } & \multirow{2}{*}{ Family } & \multirow{2}{*}{ No } & \multirow{2}{*}{ Genus } & \multirow{2}{*}{$\begin{array}{l}\text { Source } \\
\text { Soil }\end{array}$} & \multicolumn{3}{|c|}{ Isolation method } & \multicolumn{4}{|c|}{ BLAST result (\%) } & \multirow[b]{2}{*}{ Total } \\
\hline & & & & & SDS & $\mathrm{RC}$ & Total & $\geq 99$ & 98 & 97 & $\leq 96$ & \\
\hline \multirow[t]{2}{*}{1} & Micromonosporacea & 1 & Actinoplanes spp. & 2 & & 2 & 2 & 1 & 1 & & & 2 \\
\hline & & 2 & Verrucosispora spp. & 1 & & 1 & 1 & & & & 1 & 1 \\
\hline \multirow[t]{2}{*}{2} & Nocardiacea & 3 & Nocardia spp. & 1 & 1 & & 1 & 1 & & & & 1 \\
\hline & & 4 & Rhodococcus spp. & 1 & 1 & & 1 & 1 & & & & 1 \\
\hline 3 & Nocardiopsaceae & 5 & Nocardiopsis spp. & 1 & 1 & & 1 & 1 & & & & 1 \\
\hline \multirow[t]{3}{*}{4} & Streptomycetaceae & 6 & Kitasatospora spp. & 1 & 1 & & 1 & & 1 & & & 1 \\
\hline & & 7 & Streptomyces spp. & 33 & 23 & 10 & 33 & 7 & 13 & 9 & 4 & 33 \\
\hline & & 8 & Planotetraspora spp. & 1 & 1 & & 1 & & 1 & & & 1 \\
\hline \multirow[t]{2}{*}{5} & Streptosporangiaceae & 9 & Streptosporangium spp. & . 1 & & 1 & 1 & 1 & & & & 1 \\
\hline & Total & & & 42 & 28 & 14 & 42 & 12 & 16 & 9 & 5 & 42 \\
\hline
\end{tabular}

Nocardiopsaceae, and Thermomonosporaceae each appeared only one time during the course of the study. Good success of isolation is depend on variety of strategies to isolate rare and new taxa of actinomycetes. Four isolation methods used in this study have different isolates target.

Isolates belong to the genera Kineosporia family Kineosporiaceae are isolated from plant litter. It seems that their habitat is that kind of substrates and RC isolation method fit to get isolates of Kineosporia. Novel species Kineosporia mesophila was isolated from surface-sterilized stems of a pharmaceutical plant in China (Li et al. 2009) and Kineosporia babensis was isolated from plant litter in Vietnam (Sakiyama et al. 2009). The position of isolates of the family Kineosporiaceae selected in this study represented a line of descent distinct from previously described species of this family and further information are needed to describe the isolates (Fig 1).

There was only 1 species, Verrucosispora gifhornensis under the genus Verrucosispora reported previously (Rheims et al. 1998), however 5 other species were reported recently (Liao et al. 2009; Dai et al. 2010; Goodfellow et al. 2012; Xi et al. 2012; Xie et al. 2012). Isolate from CSC, Verrucosispora SP ID06A0238 is separated from those known species (Fig 2), 
Table 5 Genus diversity of actinomycetes from CSC in 2004-2006

\begin{tabular}{|c|c|c|c|c|c|c|c|c|}
\hline \multirow{2}{*}{ No } & \multirow{2}{*}{ Family } & \multirow{2}{*}{ No } & \multirow{2}{*}{ Genus } & \multicolumn{4}{|c|}{ BLAST results $(\%)$} & \multirow[b]{2}{*}{ Total } \\
\hline & & & & $\geq 99$ & 98 & 97 & $\leq 96$ & \\
\hline \multirow[t]{2}{*}{1.} & Kineo sporiaceae & 1 & Kineosporia spp. & 3 & 4 & 1 & & 8 \\
\hline & & 2 & Cryptosporangium spp. & 1 & & & & 1 \\
\hline \multirow[t]{4}{*}{2.} & Micromonosporacea & 3 & Dactylosporangium spp. & 4 & 1 & & & 5 \\
\hline & & 4 & Micromonospora spp. & 14 & 3 & & & 17 \\
\hline & & 5 & Actinoplanes spp. & 2 & 4 & 4 & & 10 \\
\hline & & 6 & Verrucosispora spp. & & & & 1 & 1 \\
\hline 3. & Mycobacteriaceae & 7 & Mycobacterium spp. & 3 & & & & 3 \\
\hline \multirow[t]{2}{*}{4.} & Nocardiacea & 8 & Nocardia spp. & 8 & 2 & & & 10 \\
\hline & & 9 & Rhodococcus spp. & 1 & & & & 1 \\
\hline 5. & Nocardioidaceae & 10 & Kribbella spp. & & 2 & & & 2 \\
\hline 6. & Nocardiospase & 11 & Nocardiopsis spp. & 1 & & & & 1 \\
\hline \multirow[t]{3}{*}{7.} & Pseudonocardiaceae & 12 & Pseudonocardia spp. & 1 & 1 & & & 2 \\
\hline & & 13 & Saccharopolyspora spp. & & 2 & & & 2 \\
\hline & & 14 & Amycolatopsis spp. & 1 & & & & 1 \\
\hline \multirow[t]{4}{*}{8} & Streptomycetaceae & 15 & Kitasatospora spp. & 1 & 3 & & & 4 \\
\hline & & 16 & Streptacidiphilus spp. & & 1 & & & 1 \\
\hline & & 17 & Streptomyces spp. & 93 & 65 & 23 & 5 & 186 \\
\hline & & 18 & Planotetraspora spp. & & 1 & & & 1 \\
\hline \multirow[t]{4}{*}{9.} & Streptosporangiaceae & 19 & Nonomuraea & 1 & 1 & 1 & & 3 \\
\hline & & 20 & Microbispora spp. & 1 & & & & 1 \\
\hline & & 21 & Microtetraspora spp. & & 1 & & & 1 \\
\hline & & 22 & Streptosporangium spp. & 1 & & & & 1 \\
\hline \multirow[t]{2}{*}{10.} & Thermomonosporaceae & 23 & Actinomadura spp. & & & 1 & & 1 \\
\hline & Total & & & 136 & 91 & 30 & 6 & 263 \\
\hline
\end{tabular}

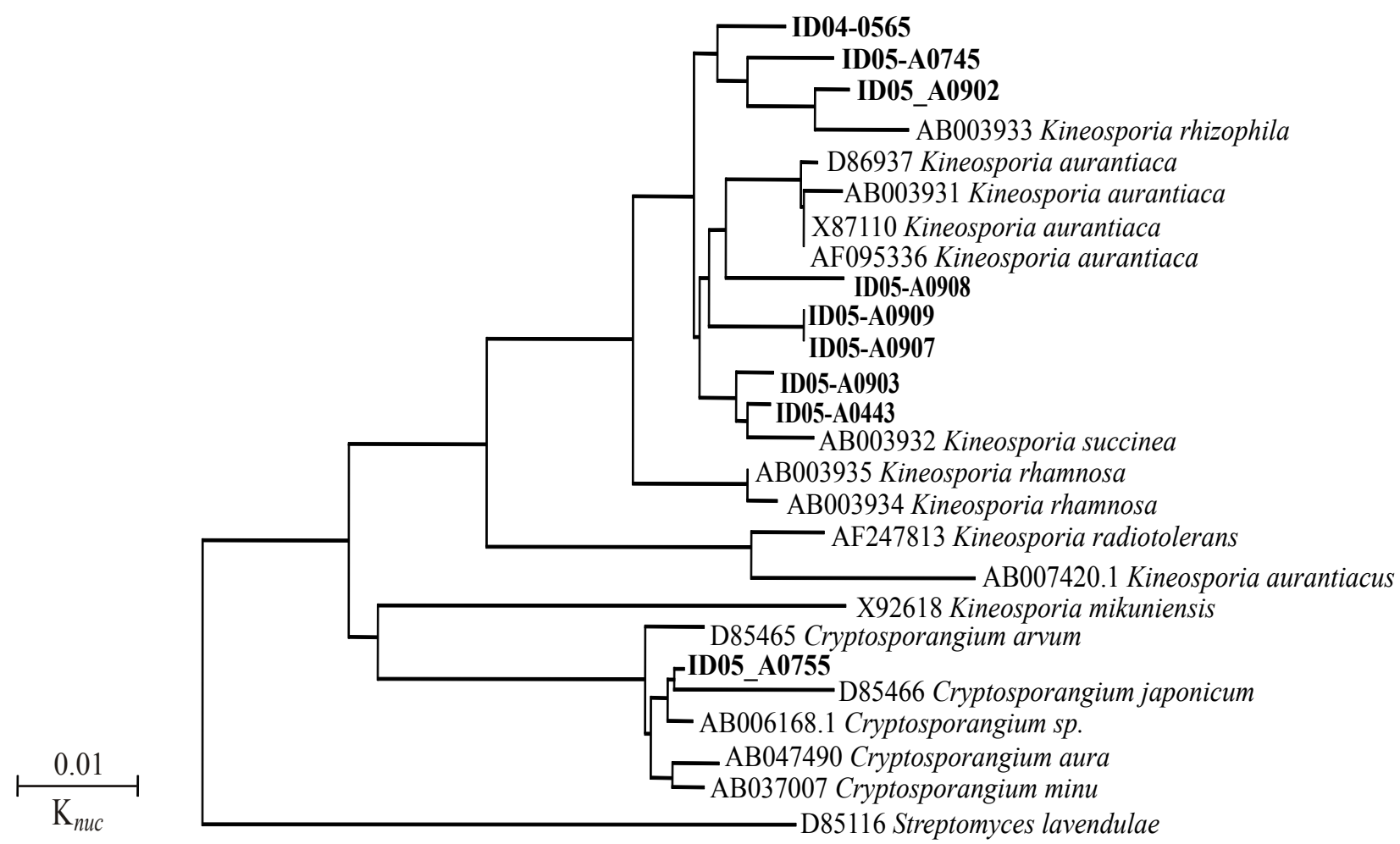

Fig 1 Phylogenetic position based on 16S rRNA sequences of several isolates under the Kineosporia genera from CSC. Bar, 1 substitution per 100 nucleotides. 


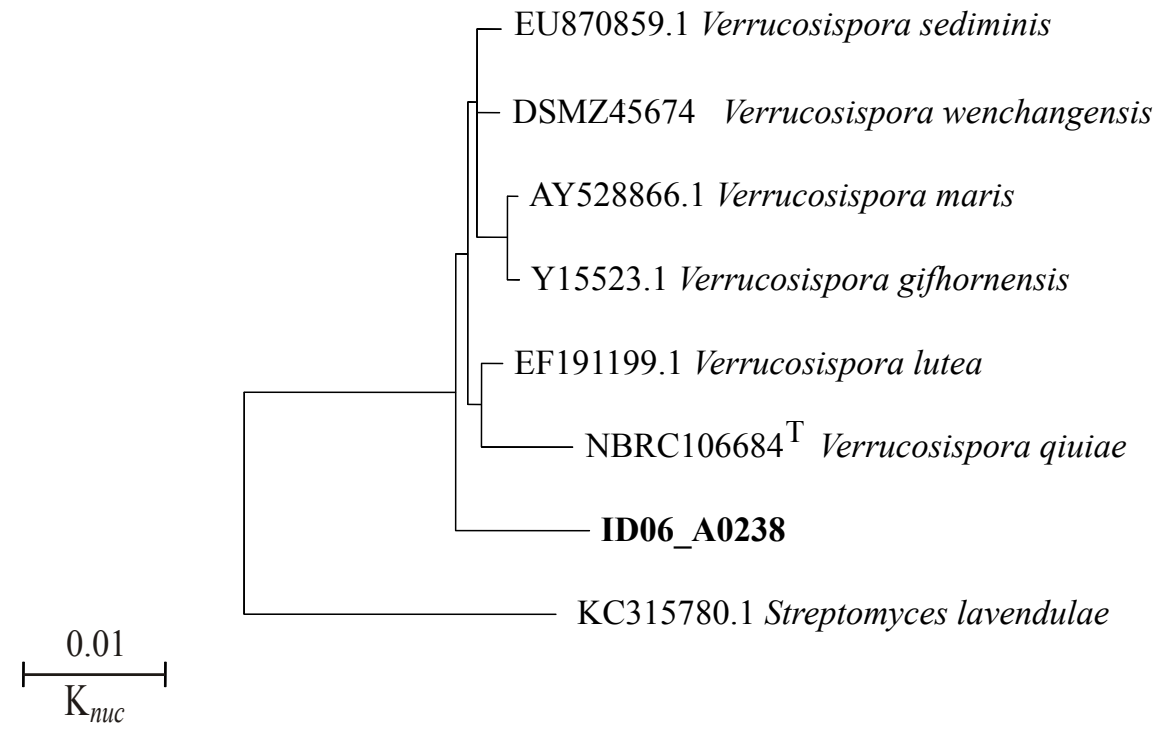

Fig 2 Phylogenetic position based on 16S rRNA sequence of isolate of Verrucosispora sp. ID06_A0238 from CSC. Bar, 1 substitution per 100 nucleotides.

therefore it is interesting candidate of new taxa and need further identification.

\section{ACKNOWLEDGMENTS}

This study was conducted under the Joint Research Project between Department of Biotechnology, National Institute of Technology and Evaluation, Japan, and the Indonesian Institute of Sciences (LIPI) representing Indonesian Government Research Institutes. The authors would like to thank Nobuyuki Goto for providing the $16 \mathrm{~S}$ rRNA gene sequences.

\section{REFERENCES}

Altschul SF, Gish W, Miller W, Myers EW, Lipman DJ. 1990. Basic local alignment search tool. J Mol Biol. 215 (3): 403-410.

Dai H-Q, Wang J, Xin Y-H, Gang Pei,Shu-Kun Tang, Biao Ren, Alan Ward, Ji-Sheng Ruan, Wen-Jun Li and Li-Xin Zhang. 2010.Verrucosispora sediminis sp. nov., a cyclodipeptide-producing actinomycete from deep-sea sediment. Int J Syst Evol Microbiol. 60(8): 18071812. doi: 10.1099/ijs.0.017053-0.

Felsenstein J. 1981. Evolutionary trees from DNA sequences: a maximum likelihood approach. J Mol Evol. 17(6): 368-376. doi: 10.1007/BF01734359.

Felsenstein J. 1985. Confidence limits on phylogenies: an approach using the bootstrap. Evolution 39(4): 783791. doi: $10.2307 / 2408678$.

Fitch WM. 1971. Toward defining the course of evolution: minimum change for a specific tree topology. Syst Zool. 20: 406-416. doi: 10.2307/2412116.

Goodfellow M, Stach JE, Brown R, Bonda AN, Jones AL, Mexson J, Fiedler HP, Zucchi TD, Bull AT. 2012.
Verrucosispora maris sp. nov., a novel deep-sea actinomycete isolated from a marine sediment which produces abyssomicins. Antonie Van Leeuwenhoek, 101(1): 185-193. doi: 10.1007/s10482-011-9651-5.

Hayakawa M, Nonomura H. 1987. Humic acid-vitamin agar, a new medium for selective isolation of soil actinomycetes. J Ferment Technol. 65(5): 501-509. doi: 10.1016/0385-6380(87)90108-7.

Hayakawa M, Nonomura H. 1989. A new method for the intensive isolation of actinomycetes from soil. Actinomycetol.3(2): 95-104.doi: 10.3209/saj.3_95.

Hayakawa M, Otoguro M, Takeuchi T, Yamazaki T, Iimura Y. 2000. Application of a method incorporating differential centrifugation for selective isolation of motile actinomycetes in soil and plant litter. Antonie van Leeuwenhoek 78(2): 171-185. doi:10.1023/A:10265 79426265 .

Ishigami M, Nakagawa Y, Hayakawa M, Iimura Y. 2004. FLO11 is essential for flor formation caused by the Cterminal deletion of NRG1 in Saccharomyces cerevisiae. FEMS Microbiol Lett. 237(2): 425-430.

Jiang Y, Wiese J, Tang S-K, Xu L-H, Imhoff J F, Jiang C-L. 2008. Actinomycetospora chiangmaiensis gen nov., sp. nov, a new member of the family Pseudonocardiaceae. Int J Syst Evol Microbiol. 58(2):408-413. doi: 10.1099/ijs.0.64976-0.

Kumar S, Tamura K, Nei M. 2004. MEGA3: integrated software for molecular evolutionary genetics analyses and sequence alignment. Brief Bioinform. 5(2): 150163. doi: 10.1093/bib/5.2.150.

Kurtböke DI. 2000. Australian Actinomycetes: An unexhausted source for biotechnological applications. Actinomycetol. 14(2): 43-53. doi: 10.3209/saj.14_43.

Li W-J, Wang D, Zhang Y-Q, Xu L-H, Jiang C-L. 2006. Kribbella yunnanensis sp. nov., Kribbella alba sp. nov., two novel species of genus Kribbella isolated from soils in Yunnan, China. Syst Appl Microbiol. 29(1): 29-35. doi: 10.1016/j.syapm.2005.06.005. 
Li J, Zhao g-Z, Huang H-Y, Qin S, Zhu W-Y, Xu L-H, Li W-J. 2009. Kineosporia mesophila sp. nov., isolated from surface-sterilized stems of Tripterygium wilfordii. Int J Syst Evol Microbiol. 59(12):3150-3154. doi: 10.1099/ijs.0.012021-0.

Liao ZL, Tang SK, Guo L, Zhang YQ, Tian XP, Jiang CL, Xu LH, Li WJ.2009.Verrucosispora lutea sp. nov., isolated from a mangrove sediment sample. Int J Syst Evol Microbiol. 59(9): 2269-2273. doi:10.1099/ijs.0.008813-0 .

Lisdiyanti P, Otoguro M, Ratnakomala S, Lestari Y, Hastuti RD, Triana E, Ando K, Widyastuti Y. 2010. Actinokineospora baliensis sp. nov., Actinokineospora cibodasensis sp. nov., Actinokineospora cianjurensis sp. nov., isolated from soil and plant litter. Int J Syst Evol Microbiol. 60(1): 2331-2335. doi:10.1099/ijs.0.013276-0 .

Nonomura H, Ohara Y. 1969. Distribution of actinomycetes in soil. VII. A culture method effective for both preferential isolation and enumeration of Microbispora and Streptosporangium strains in soil. (Part 1) Classification of the isolates. J Ferment Technol. 47: 463-469.

Otoguro M, Ratnakomala S, Lestari Y, Hastuti RD, Triana E, Widyastuti Y, Ando K. 2009. Streptomyces baliensis sp. nov., isolated from Balinese soil. Int J Syst Evol Microbiol. 59(2): 2158-2161. doi:10.1099/ijs.0.007179-0.

Otoguro M, Yamamura H, Tamura T, Irzaldi R, Ratnakomala S, Ridwan R, Kartina G, Triana E, Nurkanto A, Lestari Y, Lisdiyanti P, Widyastuti Y, Katsuhiko A. 2011. Actinophytocola timorensis sp. nov. and Actinophytocola coralina sp. nov., isolated from soil. Intl J Syst Evol Microbiol. 61(4): 834-838. doi: 10.1099/ijs.0.023432-0.

Saitou N, Nei M. 1987. The neighbor-joining method: a new method for reconstructing phylogenetic trees. Mol Biol
Evol. 4(4): 406-425.

Sakiyama Y, Thao NKN, Giang NM, Miyadoh S, Hop DV, Ando K. 2009. Kineosporia babensis sp. nov., isolated from plant litter in Vietnam. Int J Syst Evol Microbiol. 59 (3): 550-554. doi: 10.1099/ijs.0.002907-0.

Rheims H, Schumann P, Rohde M, Stackebrandt E. 1998. Verrucosispora gifhornensis gen. nov., sp. nov., a new member of the actinobacterial family Micromonosporaceae. Int J Syst Evol Microbiol. 48: 1119-1127.

Tamura T, Sakane T. 2005. Asanoa iriomotensis sp. nov., isolated from mangrove soil. Int J Syst Evol Microbiol. 55(2): 725-727. doi: 10.1099/ijs.0.02982-0.

Tamura T, Hatano K, Suzuki K. 2006. A new genus of the family Micromonosporaceae, Polymorphospora gen. nov., with description of Polymorphospora rubra sp. nov. Int J Syst Evol Microbiol. 56(8): 1959-1964. doi: 10.1099/ijs.0.64046-0.

Xie QY, Lin HP, Li L, Brown R, Goodfellow M, Deng Z, Hong K.2012. Verrucosispora wenchangensis sp. nov., isolated from mangrove soil. Antonie van Leeuwenhoek 102(1):1-7. doi: 10.1007/s10482-0129707-1.

Xi L, Zhang L, Ruan J, Huang Y. 2012. Description of Verrucosispora qiuiae sp. nov., isolated from mangrove swamp sediment, and emended description of the genus Verrucosispora. Int J Syst Evol Microbiol. 62(7):15641569. doi: 10.1099/ijs.0.033787-0.

Yamamura H, Lisdiyanti P, Ridwan R, Ratnakomala S, Saraswati R, Lestari Y, Triana E, Kartina G, Widyastuti Y, Ando K. 2010. Dietzia timorensis sp. nov., isolated from soil. Int J Syst Evol Microbiol. 60(2): 451-454. doi: 10.1099/ijs.0.012229-0 . 